\title{
Shear bond strength after dentin bleaching with $10 \%$ carbamide peroxide agents
}

\section{Resistência ao cisalhamento da dentina após clareamento com peróxido de carbamida a $10 \%$}

\author{
Roberta Tarkany Basting* \\ Patrícia Moreira de Freitas** \\ Luiz André Freire Pimenta*** \\ Mônica Campos Serra****
}

\begin{abstract}
This in vitro study evaluated the shear bond strength (SBS) of dentin treated with two $10 \%$ carbamide peroxide bleaching agents 15 days after bleaching and storage in artificial saliva. Dentin fragments were randomly divided into 3 groups $(\mathrm{n}=20)$ for the treatment with the two different bleaching agents (Rembrandt $10 \%$ or Opalescence $10 \%$ ) or with a placebo agent, applied to the tooth surface for 8 hours a day. During the remaining time, the specimens were stored in artificial saliva. After 42 days, the fragments were stored in artificial saliva for 14 days. Another group $(n=20)$ was exposed to distilled and deionized water for 56 days. An adhesive system and microhybrid composite resin were used to prepare specimens for the SBS test. SBS tests were performed and the fractured surfaces were visually examined using a stereoscope at $30 \mathrm{X}$ magnification. The analysis of variance (ANOVA) and SIDAK tests showed higher SBS values for dentin treated with Opalescence $10 \%$ than for dentin treated with Rembrandt $10 \%$ or placebo. Groups treated with Rembrandt $10 \%$, Opalescence $10 \%$ or placebo did not differ from the group treated with distilled and deionized water. Ten percent carbamide peroxide agents or a placebo agent caused no differences in SBS of dentin after 15 days of storage in artificial saliva.
\end{abstract}

DESCRIPTORS: Tooth bleaching; Dentin; Saliva, artificial.

\begin{abstract}
RESUMO: Este estudo in vitro avaliou a resistência ao cisalhamento da dentina submetida ao tratamento com dois agentes clareadores contendo peróxido de carbamida a 10\% depois de 15 dias de clareamento e armazenagem em saliva artificial. Fragmentos de dentina foram aleatoriamente distribuídos em 3 grupos $(\mathrm{n}=20)$ para receber o tratamento com dois diferentes agentes clareadores (Rembrandt a $10 \%$ ou Opalescence a 10\%) ou com um agente placebo, aplicados na superficie dental por 8 horas diárias. No restante do tempo, os espécimens permaneceram imersos em saliva artificial. Após o tratamento por 42 dias, os fragmentos foram armazenados em saliva artificial por 14 dias. Outro grupo $(n=20)$ somente recebeu a aplicação de água destilada e deionizada por 56 dias. Um sistema adesivo e uma resina composta microhíbrida foram utilizados para o preparo dos corpos-de-prova para o teste de cisalhamento. Após os ensaios, a superficie foi examinada visualmente com um estereoscópio com aumento de $30 \mathrm{X}$. A análise de variância (ANOVA) e o teste SIDAK mostraram que a dentina tratada com Opalescence a $10 \%$ apresentou maiores valores de resistência ao cisalhamento do que a tratada com o Rembrandt a $10 \%$ ou com o agente placebo. Os grupos tratados com Rembrandt a 10\%, Opalescence a $10 \%$ ou agente placebo não diferiram do grupo que recebeu somente o tratamento com água destilada e deionizada. Agentes clareadores contendo peróxido de carbamida a $10 \%$ ou um agente placebo não alteraram a resistência ao cisalhamento da dentina após 15 dias de imersão em saliva artificial.
\end{abstract}

DESCRITORES: Clareamento de dente; Dentina; Saliva artificial.

\section{INTRODUCTION}

Frequently, teeth have their color modified due to several factors, compromising esthetics. According to the etiology of the stains, the at-home bleaching technique, first described by Haywood, Heymann $^{9}(1989)$, is the best treatment, since it is effective in removing intrinsic and extrinsic stains from the teeth and also preserves the healthy dental tissues ${ }^{7,8}$.

During the bleaching process, carbamide peroxide breaks down into hydrogen peroxide and urea. The hydrogen peroxide diffuses through enamel and dentin and breaks macromolecules

\footnotetext{
* PhD, Professor, Department of Restorative Dentistry, Dental Research Center of São Leopoldo Mandic.

${ }^{* *}$ MS; ${ }^{* * *}$ DSc - Professor, Department of Restorative Dentistry, School of Dentistry, State University of Campinas. **** DSc, Professor, Department of Restorative Dentistry, School of Dentistry of Ribeirão Preto, University of São Paulo.
} 
Basting RT, Freitas PM, Pimenta LAF, Serra MC. Shear bond strength after dentin bleaching with $10 \%$ carbamide peroxide agents. Braz Oral Res 2004;18(2):162-7.

of the stains into smaller fragments, which are lighter in color, resulting in the bleaching effect ${ }^{7,9}$. The bleaching agent can also reach dentin in areas of enamel defects or abrasion, marginal areas between dentin and restorations and mainly on exposed root surfaces.

In some cases, restorations will need to be changed because their color is not clinically acceptable compared with the color attained by the natural teeth. When esthetic restorations are replaced, a bonding technique is used ${ }^{22}$. However, because the bleaching procedure affects dental tissues, bonding of some restorative materials can be compromised ${ }^{3}$. Some in vitro studies report changes in enamel ${ }^{1,10,12,15}$ and dentin ${ }^{2,3,6}$ chemical structure and/or morphology. These changes can be related to lower shear bond strength (SBS) values $^{13}$ or residual products of hydrogen peroxide degradation on dental surface that affect the polymerization of the adhesive systems and composite resins ${ }^{4,11,13,23,24}$. These changes seem to be time and concentration dependent ${ }^{19}$. The residual peroxide and/or oxygen have been claimed as factors that produce less numerous resin tags, shorter in length and less defined than those in unbleached dental structures ${ }^{23}$.

Several studies have shown that the SBS of composite to enamel is reduced when the tooth has been bleached using either an in-office or an athome technique ${ }^{4,20,21,23,24}$. However, it is suggested that dentin is more affected by hydrogen peroxide based materials due to its less mineral content and more organic matrix ${ }^{19}$. Either hydrogen peroxide or carbamide peroxide may denature dentin proteins, resulting in morphological changes that could reduce the bond between resin restorations and dentin ${ }^{13}$.

A recent study demonstrated that dentin mineral loss could be repaired by artificial saliva ${ }^{3}$ and suggests that the action of enzymes in vivo may leach all subproducts of hydrogen peroxide, even during an extended period of time, improving or maintaining SBS values.

Considering that the clinical procedure of dental bleaching consists of several applications of $10 \%$ carbamide peroxide, the present study was performed to evaluate the effect of $10 \%$ carbamide peroxide bleaching agents on dentin shear bond strength, after 2 weeks storage in artificial saliva.

\section{MATERIAL AND METHODS}

The study protocol was approved by the FOP/ UNICAMP Ethical Committee Guidelines, in accordance with the National Health Council. Twentyfive freshly extracted, nonerupted third molars, stored in $2 \%$ formaldehyde $(\mathrm{pH} 7.00)$ were used. The roots were longitudinally sectioned with double-faced diamond disks (KG Sorensen, Barueri, Brazil) in a low speed motor to obtain 80 dentin fragments. The apical third was discarded and only the cervical region was used to obtain specimens larger than $4 \times 4 \times 3 \mathrm{~mm}$. The fragments were embedded in a self-curing polyester resin in a polyvinylchloride ring mold of $2.1 \mathrm{~cm}$ in diameter so that the external surface of the dentin fragment was exposed. After resin polymerization, the external surfaces of the dentin fragments were polished with a water-cooling mechanical grinder (Maxgrind/Solotest, São Paulo, SP, Brazil) using 600-, 1,000- and 1,200-grit aluminum oxide discs (Carborundum, 3M/ESPE Dental Products, Sumaré, SP, Brazil) refrigerated with water. A uniform area of $9 \mathrm{~mm}^{2}(3 \mathrm{~mm}$ in length $\mathrm{x} 3 \mathrm{~mm}$ in width) of exposed dentin was created on the specimens by covering the remaining dental fragment with 2 coatings of nail varnish. Afterwards, the specimens were randomly assigned to four groups $(n=20)$ to apply the different treatment agents.

In this study, two brands of $10 \%$ carbamide peroxide bleaching agents were evaluated: Rembrandt 10\% (Den-Mat Corporation, Santa Maria, California, USA) and Opalescence 10\% (Ultradent Products Inc., South Jordan, Utah, USA). The placebo agent consisted of a product prepared with carbopol and glycerin (Mixed formula, Proderma - Pharmacy, Piracicaba, Brazil). The color and consistency of the placebo agent was similar to one of the bleaching agents (Opalescence 10\%), but the placebo had neutral $\mathrm{pH}$ and no carbamide peroxide (Table 1).

An individual tray for each specimen was manufactured using a $0.4 \mathrm{~mm}$ thick ethyl vinyl acetate (EVA, Bio-Art Equipamentos Odontológicos Ltda., São Carlos, Brazil) polymer in a vacuum forming machine (P7, BioArt Equipamentos Odontológicos Ltda., São Carlos, SP, Brazil). The dentin fragments of Groups G1, G2 and G3 were exposed to the treatment agents for 8 hours a day during 42 days. Although bleaching results are generally observed in 2 to 3 weeks, Haywood, Heymann ${ }^{9}$ (1989) reported that final outcome is complete in 6 weeks (42 days). A calibrated syringe was used 
Basting RT, Freitas PM, Pimenta LAF, Serra MC. Shear bond strength after dentin bleaching with $10 \%$ carbamide peroxide agents. Braz Oral Res 2004;18(2):162-7.

TABLE 1 - Groups, treatment agents, batch number, composition and manufacturers of the agents used in the experiment.

\begin{tabular}{c|l|l|l}
\hline \hline Groups & Treatment agents (batch number) & \multicolumn{1}{|c}{ Manufacturer } & \multicolumn{1}{c}{ Composition } \\
\hline G1 & $\begin{array}{l}\text { Opalescence 10\% regular } \\
\text { (3MPL) }\end{array}$ & $\begin{array}{l}\text { Ultradent Products Inc., South } \\
\text { Jordan, Utah, USA }\end{array}$ & $\begin{array}{l}\text { 10\% carbamide peroxide; } \\
\text { carbopol; glycerin; flavoring }\end{array}$ \\
\hline G2 & Rembrandt 10\% (567708) & $\begin{array}{l}\text { Den-Mat Corporation, } \\
\text { Santa Maria, California, USA }\end{array}$ & $\begin{array}{l}\text { 10\% carbamide peroxide; } \\
\text { glycerin; sodium citrate; } \\
\text { carbopol; flavor; triethanolamine }\end{array}$ \\
\hline G3 & Placebo & $\begin{array}{l}\text { Mixed formula, Proderma - } \\
\text { Pharmacy, Piracicaba, Brazil }\end{array}$ & 5\% glycerin; 1.2\% carbopol \\
\hline G4 & No treatment & \multicolumn{1}{|c}{-} \\
\hline \hline
\end{tabular}

to apply $0.02 \mathrm{ml}$ of each treatment agent to the surface of each specimen. The specimens were covered with the trays and placed into individual closed containers with $13.5 \mathrm{ml}$ of artificial saliva $(\mathrm{pH}=7.0)$, at $37 \pm 1^{\circ} \mathrm{C}$. The artificial saliva consisted of a remineralization solution proposed by Featherstone et al. ${ }^{5}(1986)$ and modified by Serra, Cury $^{18}$ (1992).

After 8 hours, the tray and the treatment agents were removed from the specimens under running distilled and deionized water for 5 seconds. During the remaining time (16 hours per day), the specimens were maintained in individual containers with $13.5 \mathrm{ml}$ of artificial saliva at $37 \pm 1^{\circ} \mathrm{C}$. The artificial saliva in the containers was daily changed. Group G4 (no treatment) was left immersed in distilled and deionized water, which was daily changed during 42 days.

After the treatment period of 42 days, the specimens were placed in individual containers with $13.5 \mathrm{ml}$ of artificial saliva, at $37 \pm 1^{\circ} \mathrm{C}$, which was changed daily, for 14 days.

The specimens were removed from the artificial saliva and the bonding area of each fragment was demarcated by placing a piece of vinyl tape, in which a $2.5 \mathrm{~mm}$ diameter hole had been punched, over the dentin surface. Then, the acid etching was performed with $35 \%$ phosphoric acid (3M/ESPE Dental Products, Sumaré, SP, Brazil) for 15 seconds. The acid was rinsed for 15 seconds under running tap water, and the dentin was dried with a gentle stream of compressed air for 5 seconds. Two consecutive coats of adhesive system (Single Bond, 3M/ESPE Dental Products, Sumaré, SP, Brazil) were applied using a saturated brush. After gently air drying for 5 seconds, the material was light cured for 10 seconds, according to the manufacturers' instructions. A manufactured Teflon ring mold $5 \mathrm{~mm}$ in height and $2.5 \mathrm{~mm}$ in diameter was placed against the specimen to receive a filling material (Filtek ${ }^{\mathrm{TM}}$ Z250, 3M/ESPE Dental Products, Sumaré, SP, Brazil). Two separate increments were placed and light-cured for 40 seconds (Optilux 500, Demetron, Danbury, CT, USA). The ring mold was removed and the composite resin was light-cured for another 20 seconds on each of the opposite sides of the resin cylinder. Light intensity was monitored using a curing radiometer connected to the light curing unit. The light intensity ranged from 550 to $650 \mathrm{~mW} / \mathrm{cm}^{2}$. The restorative procedures were done following a random sequence. The specimens were stored in a humid environment at $37^{\circ} \mathrm{C}$, for 7 days.

For the shear bond strength (SBS) tests, each specimen was positioned on a universal testing machine (Emic Ltd., São José dos Pinhais, PR, Brazil) with the dentin surface parallel to the machine's line of travel. A steel knife-edge was placed over the specimen so that the shear force was directed at the bond surface. The specimens were loaded to fail at a crosshead speed of $0.5 \mathrm{~mm} /$ minute. The fractured surfaces of the specimens were visually examined with a stereomicroscope at $30 \mathrm{X}$ magnification (Kuraray, Tokyo, Japan) by two calibrated evaluators to classify the type of failure that occurred during the debonding procedure. Failures could be: adhesive (adhesive failure); cohesive in dentin (dental substrate failure); cohesive in resin (resin failure); or mixed (cohesive in dentin and adhesive failure). The calibrated evaluators were blind to the treatment category of the specimens. They evaluated the fracture patterns in a random sequence. After reading the sample, the evaluators decided the final score for the fracture mode of the specimen. In case of disagreement, the evaluators discussed and agreed on final score. For the statistical analysis, the one-way analysis of variance (ANOVA) and SIDAK test with a significance level of $p>0.05$ were applied to SBS data. No statistical 
Basting RT, Freitas PM, Pimenta LAF, Serra MC. Shear bond strength after dentin bleaching with $10 \%$ carbamide peroxide agents.

Braz Oral Res 2004;18(2):162-7.

treatment was used in the analysis of the debonded samples, but a descriptive method was used.

\section{RESULTS}

The analysis of variance and Sidak tests showed differences in SBS among the treatment agents evaluated. Mean SBS values and standard deviations for each group are shown in Table 2. There were statistical differences for SBS values of dentin treated with the placebo and Rembrandt $10 \%$ compared to Opalescence $10 \%$. There were no statistically significant differences in SBS values between all the treatment groups and G4, whose specimens were maintained in distilled and deionized water for 56 days.

The examination of the debonded samples with a stereomicroscope at $30 \mathrm{X}$ magnification showed that the fractures were predominantly adhesive for the agents, as shown in Table 3.

\section{DISCUSSION}

The possibility that bleaching might be detrimental to bonding procedures on dentin, increasing microleakage and consequently secondary caries, is still questioned. The suggestion that dentin can be more affected by hydrogen peroxide based materials due to its less mineral content and more organic matrix ${ }^{19}$ is supported because either hydrogen peroxide or carbamide peroxide may denature dentin proteins, resulting in morphologi- cal changes that could reduce the performance of resin bonded restorations ${ }^{13}$.

The exposure of dentin to bleaching agents has been shown to reduce microhardness values ${ }^{3}$ and these alterations in the dentinal organic/inorganic composition may also result in changes in the mechanical properties of dentin ${ }^{17}$. Rotstein et $a{ }^{16}{ }^{16}$ (1996) also reported that bleaching with carbamide peroxide results in lower concentrations of calcium and phosphate compared with unbleached dentin. Considering that there is a relation between the amount of calcium on the surface and dentin bonding ${ }^{14}$, low SBS values of dentin after bleaching were expected in this study. Our results suggest that possible morphological or structural changes in dentin were repaired during the elapsed time between bleaching and the restorative procedure, while teeth were stored in artificial saliva. Thus, this remineralizing solution for 14 days seems to restore dentin properties and contribute to an optimal adhesion after the exposure to bleaching agents for 42 days $^{3}$.

Perdigão et al. ${ }^{13}$ (1998) suggested that changes in dentin morphology in vivo might undergo repair over time by precipitation of mineral from saliva. In this study, during and after the proposed bleaching treatment, samples were kept immersed in artificial saliva, which contains calcium and phosphate ions ${ }^{18}$. This might have contributed to mineral gain and, consequently, raised SBS values.

The reduction in SBS values might be caused by oxygen accumulation in dentin - released dur-

TABLE 2 - Mean shear bond strength values, standard deviation and range of each group.

\begin{tabular}{c|l|c|c|c|c}
\hline \hline Group & \multicolumn{1}{|c|}{ Treatment agents } & Mean & Standard deviation & Range & $\mathrm{p}>0.05^{*}$ \\
\hline G1 & Opalescence 10\% & 13.85 & 4.22 & $8.08-23.37$ & $\mathrm{a}$ \\
\hline G2 & Rembrandt 10\% & 11.12 & 3.96 & $4.45-17.31$ & $\mathrm{~b}$ \\
\hline G3 & Placebo & 9.81 & 4.02 & $2.95-17.88$ & $\mathrm{~b}$ \\
\hline G4 & No treatment & 10.60 & 3.85 & $5.93-18.98$ & $\mathrm{ab}$ \\
\hline \hline
\end{tabular}

*Statistical differences expressed by different letters $(\mathrm{p}<0.05)$.

TABLE 3 - Failure mode analysis and percentages of coincident failure mode data as evaluated by two evaluators for the treatment agents.

\begin{tabular}{l|c|c|c|c}
\hline \hline \multicolumn{1}{c|}{ Treatment agents } & Adhesive & Cohesive/dentin & Cohesive/resin & Mixed \\
\hline Opalescence $10 \%$ & $11(91.67 \%)$ & $1(8.33 \%)$ & $0(0 \%)$ & $0(0 \%)$ \\
\hline Rembrandt $10 \%$ & $11(91.67 \%)$ & $1(8.33 \%)$ & $0(0 \%)$ & $0(0 \%)$ \\
\hline Placebo & $11(91.67 \%)$ & $1(8.33 \%)$ & $0(0 \%)$ & $0(0 \%)$ \\
\hline No treatment & $11(91.67 \%)$ & $1(8.33 \%)$ & $0(0 \%)$ & $0(0 \%)$ \\
\hline \hline
\end{tabular}


Basting RT, Freitas PM, Pimenta LAF, Serra MC. Shear bond strength after dentin bleaching with $10 \%$ carbamide peroxide agents. Braz Oral Res 2004;18(2):162-7.

ing the decomposition of the bleaching agent since dentin may act as an important oxygen reservoir ${ }^{13,19,23}$. Thus, a delay in restorative procedures is recommended after bleaching, ranging from 24

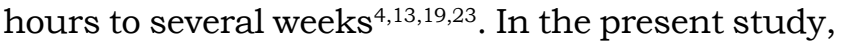
all the specimens were kept in a remineralizing solution for 2 weeks prior to restorative procedures. The results revealed that saliva, used to simulate oral conditions, contributed to mineral enhancement, as SBS values for the treated groups were similar to those from the unbleached group.

Since SBS tests have been criticized because of their mechanics ${ }^{25,26}$, it is essential that the interface of the adhesive fracture be observed, in order to evaluate the pattern of the fracture. The evaluation of the fracture modes showed mostly adhesive failures for all the treatment agents evaluated. Although the correlation between SBS and failure patterns was not statistically evaluated and visual inspection of fractured sample surfaces with light microscopy may not truly expose the actual nature of the fractures as compared to a SEM evaluation ${ }^{27}$, this data shows that $10 \%$ carbamide peroxide bleaching agents and placebo can induce failures in adhesion. Besides, evaluations with light microscopy are inexpensive and easily performed.

The increasing quality of adhesive materials could also be a reason for the occurrence of just one dentin cohesive failure for each treatment. An ethanol and water based adhesive system was used in our experiment. Ethanol is known to reduce the surface water and increase SBS ${ }^{11,21}$.

\section{REFERENCES}

1. Basting RT, Rodrigues AL Jr, Serra MC. The effects of seven carbamide peroxide bleaching agents on enamel microhardness over time. J Am Dent Assoc 2003;134(10):133542.

2. Basting RT, Rodrigues Junior AL, Serra MC. The effect of $10 \%$ carbamide peroxide bleaching material on microhardness of sound and demineralized enamel and dentin in situ. Oper Dent 2001;26:531-9.

3. de Freitas PM, Basting RT, Rodrigues JA, Serra MC. Effects of two $10 \%$ peroxide carbamide bleaching agents on dentin microhardness at different time intervals. Quintessence Int 2002;33:370-5.

4. Dishman MV, Covey DA, Baughan LW. The effects of peroxide bleaching on composite to enamel bond strength. Dent Mater 1994;10:33-6.

5. Featherstone JDB, O'Really MM, Shariati M, Brugler S. Enhancement of remineralization in vitro and in vivo. In: Leach SA, editor. Factors relating to demineralisation and
This water-chasing behavior of this solvent was expected to be accentuated in dentin, owing to its intrinsic wetness. This could be confirmed in an experiment performed by Spyrides et al. ${ }^{19}$ (2000), demonstrating that the use of Single Bond - an ethanol based adhesive - on dentin treated with a $10 \%$ carbamide peroxide agent did not seem to reverse the reduction in SBS values. The values appear to be related to the presence of a remineralizing solution and to the period elapsed between the bleaching and the restorative treatment. Furthermore, the results show that dentin bleached with $10 \%$ carbamide peroxide agents or exposed to placebo, when subjected to shear bond forces, show preservation of the dental structure.

\section{CONCLUSIONS}

The hypothesis that residual peroxide and/or oxygen are factors that affect the polymerization of the adhesive systems and composite resins may be taken into account, since $10 \%$ carbamide peroxide agents or a placebo agent caused no differences in SBS of dentin to an adhesive system after 15 days of storage in artificial saliva.

\section{ACKNOWLEDGEMENTS}

We would like to thank the financial support of PIBIC-CNPq (National Council for Scientific and Technological Development) (grants 99/10829$3)$.

remineralisation of the teeth. Oxford: IRL; 1986. p. 2334.

6. Garcia-Godoy F, Dodge WW, Donohue M, O'Quinn JA. Composite resin bond strength after enamel bleaching. Oper Dent 1993;18:144-7.

7. Goldstein GR, Garber DA. Complete dental bleaching. Chicago: Quintessence Books; 1995.

8. Haywood VB. History, safety and effectiveness of current bleaching techniques and applications of the nightguard vital bleaching technique. Quintessence Int 1992;23:47188.

9. Haywood VB, Heymann HO. Nightguard vital bleaching. Quintessence Int 1989;20:173-6.

10. Josey AL, Meyers IA, Romaniuk K, Symons AL. The effect of a vital bleaching technique on enamel surface morphology and the bonding of composite resin to enamel. J Oral Rehabil 1996;23:244-50. 
Basting RT, Freitas PM, Pimenta LAF, Serra MC. Shear bond strength after dentin bleaching with $10 \%$ carbamide peroxide agents. Braz Oral Res 2004;18(2):162-7.

11. Kalili T, Caputo AA, Mito R, Sperbeck G, Matyas J. In vitro toothbrush abrasion and bond strength of bleached enamel. Pract Periodontics Aesthet Dent 1991;3:22-4.

12. McGuckin RS, Thurmond BA, Osovitz S. Enamel shear bond strengths after vital bleaching. Am J Dent 1992;5:216-22.

13. Perdigão J, Francci C, Swift EJ, Ambrose WW, Lopes M. Ultra-morphological study of the interaction of dental adhesives with carbamide peroxide-bleached enamel. Am J Dent 1998;11:291-301.

14. Perinka L, Sano H, Hosoda H. Dentin thickness, hardness and Ca-concentration vs. bond strength of dentin adhesives. Dent Mater 1992;8:229-33.

15. Rodrigues JA, Basting RT, Serra MC, Rodrigues Junior AL. Effects of $10 \%$ bleaching materials on enamel microhardness. Am J Dent 2001;14:67-71.

16. Rotstein I, Dankner E, Goldman A, Heling I, Stabholz A, Zalkind M. Histochemical analysis of dental hard tissues following bleaching. J Endod 1996;22:23-5.

17. Seghi RR, Denry I. Effects of external bleaching on indentation and abrasion characteristics of human enamel in vitro. J Dent Res 1992;71:1340-4.

18. Serra MC, Cury JA. The in vitro effect of glass-ionomer cement restoration on enamel subjected to a demineralization and remineralization model. Quintessence Int 1992;24:39-44.
19. Spyrides GM, Perdigão J, Pagani C, Araujo MA, Spyrides SM. Effect of whitening agents on dentin bonding. $\mathrm{J}$ Esthet Dent 2000;12:264-70.

20. Stokes AN, Hood JAA, Dhariwal D, Patel K. Effect of peroxide bleaches on resin-enamel bonds. Quintessence Int 1992;23:769-71.

21. Sung EC, Chan SM, Mito R, Caputo AA. Effect of carbamide peroxide bleaching on the shear bond strength of composite to dental bonding agent enhanced enamel. J Prosthet Dent 1999;82:595-9.

22. Swift EJ, Perdigão J. Effects of bleaching on teeth and restorations. Compend Contin Educ 1998;19:815-20.

23. Titley KC, Torneck CD, Ruse ND, Krmec D. Adhesion of a resin composite to bleached and unbleached human enamel. J Endod 1993;19:112-5.

24. Torneck CD, Titley KC, Smith DC, Adibfar A. The influence of time of hydrogen peroxide exposure on the adhesion of composite resin to bleached bovine enamel. J Endod 1990;16:123-8.

25. van Noort R, Noroozi S, Howard IC, Cardew G. A critique of bond strength measurements. J Dent 1989;17:617.

26. Versluis A, Tantbirojn D, Douglas WH. Why do shear bond tests pull out dentin? J Dent Res 1997;76:1298307.

27. Zidan O, Asmussen E, Jorgensen KD. Microscopical analysis of fractured restorative resin/etched enamel bonds. Scand J Dent Res 1982;90:286-91.

Received for publication on Dec 17, 2003 Accepted for publication on Apr 26, 2004 